\title{
Early detection of sources of resistance to the fall armyworm in some tropically-adapted maize varieties in Southern Nigeria
}

\author{
Qudrah Olaitan OLOYEDE-KAMIYO*, Oluwakemi Oluwaseyi ODEYEMI
}

Received October 29, 2020; accepted April 29, 2021. Delo je prispelo 29. oktobra 2020, sprejeto 29. aprila 2021.

\begin{abstract}
Early detection of sources of resistance to the fall armyworm in some tropically-adapted maize varieties in Southern Nigeria

Abstract: The outbreak of fall armyworm (FAW), Spodoptera frugiperda, in Nigeria since 2016 had caused serious socioeconomic problem to farmers. Twenty maize varieties adapted to the agro-ecologies of Nigeria were evaluated in five environments to identify varieties with resistance to the FAW for possible improvement and deployment. The evaluations were under artificial and natural infestation between 2017 and 2018 . Data were collected weekly after infestation on severity and incidence of FAW and plant height. All trials were terminated at six weeks after sowing. Varieties SUWAN 1 SR, BR LNTP-Y C, AMA TZBR-W $\mathrm{C}_{4}$ and TZBR ELD $4 \mathrm{C}_{2}$ are good sources of resistance to FAW which could be used in improvement program.

Key words: crop improvement; fall armyworm; insect infestation, maize; pest resistance, Africa.
\end{abstract}

\begin{abstract}
Zgodnje odkrivanje na ameriško koruzno sovko (Spodoptera frugiperda [J. E. Smith, 1797]) odpornih in tropom prilagojenih sort koruze $v$ južni Nigeriji

Izvleček: Močan pojav ameriške koruzne sovke (Spodoptera frugiperda [J. E. Smith, 1797]) kmetom v Nigeriji od leta 2016 povzroča resne socio-ekonomske težave. $\mathrm{V}$ pričujoči raziskavi je bilo ovrednotenih dvajset sort koruze, prilagojenih agro-ekološkim razmeram v Nigeriji. Na petih lokacijah so preučevali odpornost sort na škodljivca, $\mathrm{z}$ namenom njihovega izboljšanja in uvajanja v pridelavo. Ocenjevanja so potekala $\mathrm{v}$ letih 2017 in 2018 v naravnih razmerah in v rastlinjaku. Podatki o pojavu škodljivca, obsegu poškodb zaradi gosenic in višini rastlin so se zbirali tedensko. Vsi poskusi so bili končani šest te-

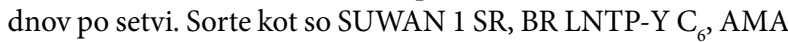
TZBR-W $\mathrm{C}_{4}$ in TZBR ELD $4 \mathrm{C}_{2}$ so se izkazale kot dober vir odpornosti na škodljivca in bi lahko bile uporabljene v programih za izboljšanje učinkovitosti zatiranja ameriške koruzne sovke.

Ključne besede: izboljšanje poljščin; ameriška koruzna sovka; napadenost $\mathrm{z}$ žuželkami; koruza; odpornost na škodljivce; Afrika.
\end{abstract}

Institute of Agricultural Research and Training (IAR\&T), Obafemi Awolowo University, P.M.B. 5029, Moor Plantation, Apata, Ibadan, Nigeria

* Corresponding author: Qudrah Olaitan Oloyede-Kamiyo

Address: Maize Improvement Programme for Southern ecology, IAR\&T, Moor Plantation, Ibadan, Nigeria

Email address: qudratkamiyo@gmail.com

Tel. No.: +2348060993930

Orcid ID: 0000-0002-9409-0259 


\section{INTRODUCTION}

Maize (Zea mays L.) yield is limited by several biotic and abiotic stresses. Insect pests are one of the major biotic stresses contributing to yield losses of crops in the field with high socio-economic impact. Various control measures are employed which include use of chemicals, cultural control and use of bio-pesticides. For instance, entomopathogenic nematodes have been reported to significantly reduce number of larvae of Colorado potato beetles, but high cost of the agent limits its use (Laznik et al., 2010). Stem borers used to be the common insect pests of maize especially in the forest zone of Nigeria causing between $20-40 \%$ yield losses (Oloyede-Kamiyo et al., 2011). The fall armyworm (FAW), Spodoptera frugiperda (J.E. Smith) (Lepidoptera: Noctuidae) also of the family Lepidoptera, has been in Africa for approximately 10 years but in the early 2016, there was an outbreak of the pest on maize in southwest Nigeria. A survey carried out in 2016 by Institute of Agricultural Research and Training (I.A.R.\&T), Ibadan showed that the pest is widespread, especially in the southwest and some southern states. By the end of that year, it has spread to the northern part of the country causing majority of farmers to abandon their farms. The larvae of the pest were observed to have caused as high as $100 \%$ damage on maize fields, attacking virtually all the growth stages of the maize crop, from the vegetative stage to cob formation. The menace of this pest has caused loss of millions of dollars especially to commercial farmers who invest with loan from banks, hence posing a serious economic threat to the food security of the country. The report commissioned by the Department for International Development, indicates that the arrival of fall armyworm in Africa has the potential to cause maize yield losses in a range of 8.3 to 20.6 million tonnes per annum, in the absence of any control measure in just 12 maize-producing countries. (Abrahams et al., 2017). FAW has recorded long history of resistance to pesticides and GM toxins (Huesing, 2017). Several insecticides have been tested on the insect since its arrival in Nigeria in 2016 with little success. The heavy dose of different types of insecticide used has long-term effect on the health of maize farmers and even the end-users. Development of resistance lines is very crucial to combat the menace and eliminate the health hazard of persistent use of insecticides. In developing FAW resistant maize varieties, there is need to identify resistant source from the existing varieties. Some promising lines have been identified and validated by CIMMYT and KALRO, Kiboko, Kenya (Prasanna, 2018). There is need to identify varieties with resistance to the FAW among the varieties adapted to the agro-ecologies of Nigeria for possible improvement and deployment.
This study therefore aims at detecting maize varieties with resistance to the FAW at early growth stage among the adapted varieties in Southern Nigeria.

\section{MATERIAL AND METHODS}

Twenty open-pollinated maize varieties were evaluated in five environments at different out-stations of the Institute of Agricultural Research and Training (IAR\&T), Ibadan, Nigeria, under natural and artificial FAW infestation between 2017 and 2018. The varieties were sourced from the International Institute of Tropical Agriculture (IITA), and Institute of Agricultural Research and Training (IAR\&T), Ibadan, Nigeria. Some of varieties used have undergone cycles of recurrent selection for resistance to stem borer species, Sesamia calamistis (Hampson) and Eldana saccharina (Walker). The maize varieties used with their attributes are presented in Table 1.

Out of the five environments, one was under artificial infestation in the screen house in Ibadan (Lat. $7^{\circ}$ $24^{\prime} 7.06^{\prime \prime} \mathrm{N}$, Long. $3^{\circ} 55^{\prime} 2.33^{\prime \prime} \mathrm{E}, 225 \mathrm{~m}$ above sea level) in November 2017. The remaining four environments were under natural infestation on the field at Amakama in the humid rain forest (Lat. $5^{\circ} 26^{\prime} 40^{\prime /} \mathrm{N}$, long. $7^{\circ} 28^{\prime} 49^{\prime /} \mathrm{E}$, $154.25 \mathrm{~m}$ above sea level), Ikenne in rain forest (Lat. $6^{\circ}$ $51^{\prime} 57^{\prime /} \mathrm{N}$, Long. $3^{\circ} 42^{\prime} 55^{\prime /} \mathrm{E}, 70 \mathrm{~m}$ above sea level), and early and late seasons in Ibadan in derived savanna of Nigeria. The field evaluated commenced in April 2018 (early season in Ibadan), June 2018 in Ikenne and Amakama, and in October 2018 for late season in Ibadan. The experiment was laid out in a randomized complete design in three replications. Each plot on the field was a two-row plot of $5 \mathrm{~m}$ long with plant spacing of $75 \mathrm{~cm}$ between rows and $50 \mathrm{~cm}$ within rows with two plants per stand. No insecticide was used to control S. frugiperda, being the only major pest around. However, other agronomic practices were carried out appropriately. Pre-emergence herbicide, comprising mixture of atrazine (Southern AG) and paraquat (Syngenta, United states) was used a day after planting, with one manual weeding at four weeks after planting. NPK fertilizer and urea were applied at 10 days and 4 weeks after planting, respectively at the rate of $60 \mathrm{~kg} \mathrm{~N} \mathrm{ha}^{-1}$ each. For the artificial infestation in the screen house, each plant was infested with average of six first instar larvae at two weeks after planting using camel hair brush.

Data collection started in the screen house at a week after infestation, while data commenced on the field at a week after the first notice of infestation on the plants. Plant height was taken in centimeter on five tagged plants per plot using ruler. Severity of infestation was rated per plot on a scale of 1-9 based on the level of feeding on the 
leaves, presence of frass, and overall effects on the plants (Prasanna, 2018). Incidence of infestation was taken by counting the number of plants infested by the pest per plot and expressed as percentage of plant stands per plot. All data were taken weekly till termination of the experiment. The trials were terminated at six weeks after sowing (WAP).

Percentage data were transformed using arcsine before analysis. Means were separated using least significant difference (LSD). Combined analysis of variance was performed using SAS, version 9.2. Rank Summation Index (RSI) of Mulumba and Mock (1978) was used to rank the varieties according to their level of resistance using severity and incidence at 1 and 4 weeks after infestation as selection criteria. Principal component analysis was conducted to determine the contribution of the traits to the observed variation. The traits contributing most were then used to perform cluster analysis. Similarities were measured based on Euclidean distance.

Table 1: Maize varieties used for the study with their attributes

\begin{tabular}{|c|c|c|c|c|}
\hline $\mathrm{s} / \mathrm{n}$ & Name & Kernel colour & ${ }^{*}$ Source & ${ }^{*}$ Attribute \\
\hline 1 & TZBR COMP $1-\mathrm{Y} \mathrm{C}_{3}$ & Yellow & IITA & Stem borer resistant \\
\hline 2 & SUWAN-1-SR-Y & Yellow & IITA & Streak resistant \\
\hline 3 & TZBR COMP-1-W $\mathrm{C}_{2}$ & White & IITA & Stem borer resistant \\
\hline 4 & TZPB-SR-W & White & IITA & Streak resistant \\
\hline 5 & TZBR COMP-2-Y $\mathrm{C}_{3}$ & Yellow & IITA & Stem borer resistant \\
\hline 6 & ART/98/SW1 & Yellow & IAR\&T & High protein maize \\
\hline 7 & TZBR ELD 4-Y C ${ }_{2}$ & Yellow & IITA & Resistant to stem borer (Eldana sp.) \\
\hline 8 & ART/98/SW6-OB & White & IAR\&T & Quality protein maize \\
\hline 9 & TZBR COMP-2-W $\mathrm{C}_{2}$ & White & IITA & Stem borer resistant \\
\hline 10 & TZE-COMP5 & White & IITA & Striga resistant \\
\hline 11 & BR9928 DMRSR & Yellow & IAR\&T & Resistant to stem borers, downy mildew and streak \\
\hline 12 & ART/98/ILE-1-OB & White & IAR\&T & Quality protein maize \\
\hline 13 & AMA TZBR-Y $C_{1}$ & Yellow & IITA & Stem borer resistant \\
\hline 14 & DMR-ESR-Y & Yellow & IAR\&T & Downy mildew and Streak resistance \\
\hline 15 & BR LNTP-Y C 6 & Yellow & IITA & Stem borer resistant, tolerant to low soil nitrogen \\
\hline 16 & PRO-VIT. A & Yellow & IAR\&T & Provitamin A enriched \\
\hline 17 & AMA TZBR-W $\mathrm{C}_{4}$ & White & IITA & Stem borer resistant \\
\hline 18 & TZE BR-ELD3-W & White & IITA & Resistant to stem borer (Eldana sp.) \\
\hline 19 & TZBR ELD 4-W C ${ }_{2}$ & White & IITA & Resistant to stem borer (Eldana sp.) \\
\hline 20 & BR9943 DMRSR & White & IAR\&T & Resistant to stem borers, downy mildew and streak \\
\hline
\end{tabular}

${ }^{\star}$ The attributes are from the names of the varieties. The source indicated the producers of the varieties.

TZBR: Tropical Zea Borer Resistance; SR: Streak Resistance; DMRSR: Downy Mildew Resistance Streak Resistance; ELD: Eldana; IITA: International Institute of Tropical Agriculture; IAR\&T: Institute of Agric. Research and Training 


\section{RESULTS}

The weekly FAW severity and incidence level is presented in Table 2. Severity was high at early stage (1-2 weeks after infestation) but reduced as the plant grow older. FAW incidence varied among the maize varieties. It increased over time in some, while it reduced in some. The level of severity and incidence was more pronounced under artificial infestation than natural infestation. Severity was the least in 'TZBR ELD 4-W C' ' under natural infestation, and in 'TZBR COMP2-Y $\mathrm{C}_{3}$ ' under artificial infestation. FAW incidence reduced drastically in 'BR9943 DMRSR' from 1-4 weeks after infestation (23.6 $\%, 15.6 \%, 5.8 \%$ and $4.2 \%$ respectively) under natural infestation, and in 'TZPB SR-W' under artificial infestation ( $83.3 \%, 58.3 \%, 16.7 \%$ and $0 \%$ respectively).

Mean square of variety was significant for severity and plant height at one week after infestation under artificial infestation (Table 3), while under natural infestation (Table 4), mean square of environment and mean square of variety were significant for almost all the traits. Mean squares of environment by variety interaction was also significant for severity at 3 weeks after infestation, incidence at 2 and 4 weeks after infestation, and plant height at land 3 weeks after infestation (Table 4).

The top $25 \%$ maize variety selected using RSI is presented in Table 5. Three of the five maize varieties selected under artificial infestation are stemborer resistant varieties. The $\mathrm{BR}$ LNTP-Y $\mathrm{C}_{6}$ selected as the best resistant variety under artificial infestation has been tested at IITA to be resistant to the FAW. 'ART/98/SW6-OB' is a quality protein maize.

Variety developed by IAR\&T, while SUWAN 1 SR is an old variety, resistant to streak. All the maize selected under natural infestation are stem borer resistant varieties except 'SUWAN 1 SR-W. SUWAN 1 SR-W', 'AMATZBR-W C' ' and 'TZBR ELD 4' were commonly selected under both conditions although the white version of 'TZBR ELD 4' was selected under natural infestation.

The result of principal component analysis revealed that PCA 1,2 and 3 accounted for $85.5 \%$ and $87.9 \%$ of the variations observed under artificial and natural infestation respectively (Table not shown). The variables responsible for the observed variation under artificial infestation were incidence at $1,2,3$ and 4 weeks after infestation, while incidence at 1, 2, 3 and 4 weeks after infestation and plant height at 3 and 4 weeks after infestation were responsible for the variations under natural infestation.

At $50 \%$ similarity distance, 9 distinct groups were formed under artificial infestation (Figure 1). Varieties TZBR Comp 1-W (G1), BR LNTP-Y C (G5), SUWAN 1 SR (G6), BR9928 DMRSR (G7) and TZPB SR (G9) stood alone in their groups. 'ART/98/SW6-OB' and 'TZBR ELD $4-\mathrm{Y} \mathrm{C}_{2}$ ' clustered together in a group (G4). Other varieties clustered in three different groups. However, at 50 $\%$ similarity distance, six distinct groups were formed under natural infestation (Figure 2). Varieties BR9943DMRSR (G1), TZEBR ELD 3-W (G3), AMATZBR-Y C (G5) stood alone in their groups. 'BR LNTP-Y C', 'AMATZBR-W C', 'DMRESR-Y', 'TZBR Comp-Y $\mathrm{C}_{3}$ ' and 'TZBR ELD 4-W C ' clustered together in a group (G2), while others clustered in two other groups.

It is worth noting here that the top varieties selected by RSI under artificial infestation fell in the best groups in the dendrogram $(G 4,5 \& 6)$. Similar result was observed under natural infestation. The varieties selected by RSI clustered in G1 and G2 in the dendrogram in cluster analysis.

\section{DISCUSSION}

The economic effect of the fall armyworm could be determined on the field at early growth stage of maize plant through random sampling on the field, location of infestations in the field, larval size, and where the larvae are feeding on the plant. Hence, levels of infestation at this stage, especially under artificial infestation or hot spots suggest the inherent resistance of each maize variety to the pest. In the present study, it was observed that severity and incidence level reduced over time in some of the varieties although at different pace. The resistance check, 'BR LNTP-Y C.' had its severity and incidence level reduced to 1 and $8 \%$ respectively, after 4 weeks of infestation. This was comparable to what was observed in some other varieties such as ART/98/ SW6-OB, TZPB SR and TZBR ELD 4-Y C . Ni et al. (2011) had similar observation in some of the germplasms evaluated. This observation suggested that the varieties had the ability to tolerate/overcome the effects of FAW. Hence, substantial level of resistance to the fall armyworm was indicated in them. Williams et al. (1998) reported that maize that is resistant to FAW sustained less leaf-feeding damage, and larvae feeding on resistant maize grew more slowly. Some promising CIMMYT maize inbreds identified and validated in Kiboko, Kenya had their leaf damage ratings between 2.0 and 6.0 (Prasanna, 2018). This rating was similar to what was obtained in the present study.

The significant mean squares of environment, variety and the environment by variety interaction for most of the traits under natural infestation was similar to those observed by Giaveno et al. (2004), Giaveno and Ferrero (2003) and $\mathrm{Ni}$ et al. (2011). The significant environment by variety interaction observed for incidence and severity of FAW could be due to erratic performance across 


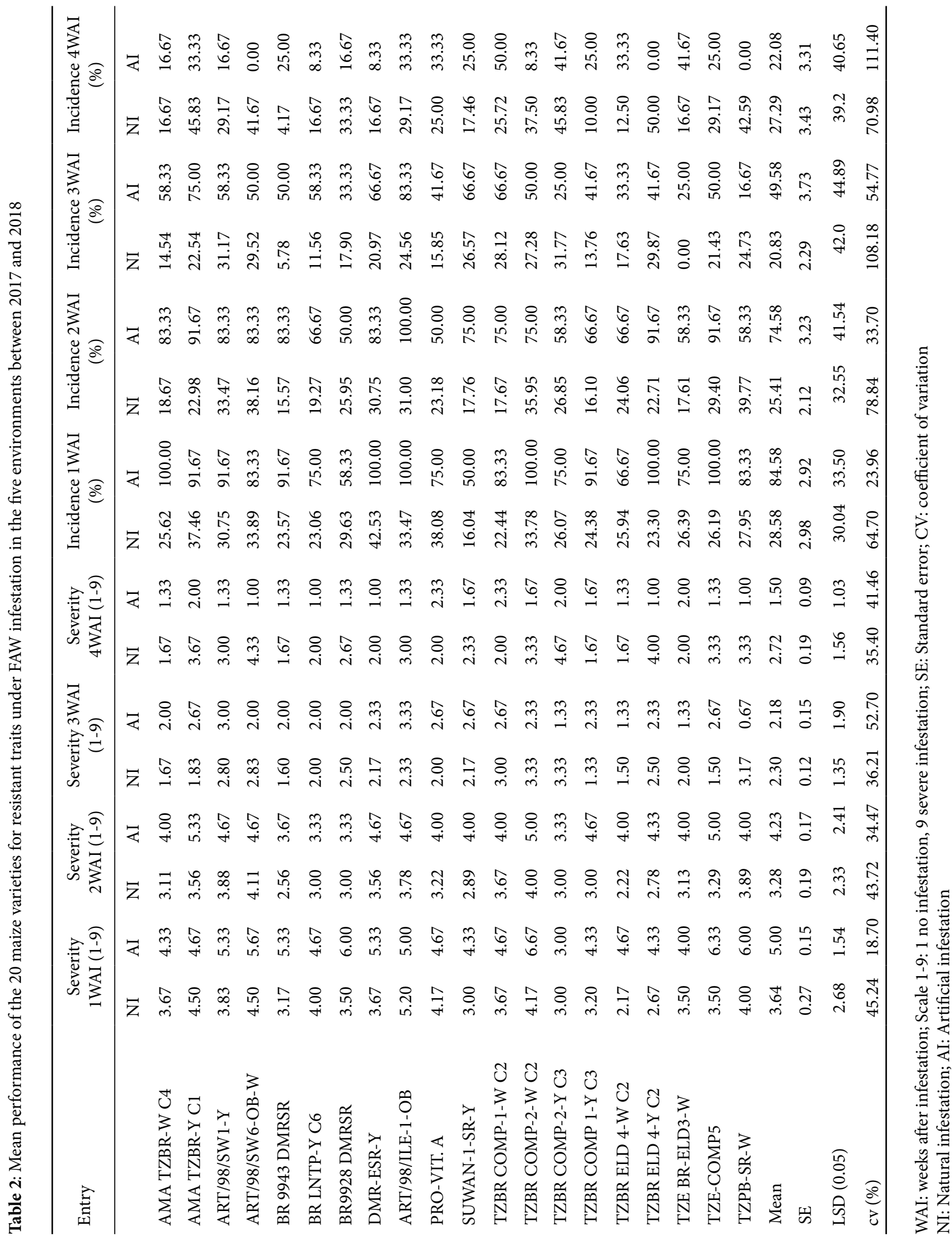


Table 3: Mean squares from analysis of variance for the traits studied under artificial infestation in Ibadan in 2017

\begin{tabular}{lccccccccccccc}
\hline Source & df & INC 1 & INC 2 & INC 3 & INC 4 & SVR 1 & SVR 2 & SVR 3 & SVR 4 & PH 1 & PH 2 & PH 3 & PH 4 \\
\hline Variety & 19 & 0.17 & 0.13 & 0.18 & 0.16 & $2.31^{\star *}$ & 1.02 & 1.25 & 0.58 & $13.24^{*}$ & 29.1 & 42.26 & 52.11 \\
Rep & 2 & 0.20 & 0.07 & 0.39 & 0.44 & 2.62 & 3.22 & 1.52 & 0.65 & 1.01 & 25.54 & 18.60 & 38.90 \\
Error & 38 & 0.10 & 0.15 & 0.14 & 0.13 & 0.86 & 2.13 & 1.32 & 0.39 & 7.08 & 16.93 & 26.23 & 39.41 \\
\hline
\end{tabular}

SVR 1,2,3\&4: FAW severity (scale1-9) at 1,2,3\&4 weeks after infestation; INC 1, 2,3 \& 4: FAW incidence (\%) at 1, 2, 3 \& 4 weeks after infestation; PH 1, 2, 3 \& 4: Plant height at 1,2, 3 \& 4 weeks after infestation; df: degree of freedom; ${ }^{*}{ }^{* *}:$ Significant at $p=$ 0.05 and 0.01 respectively

Table 4:. Mean squares from analysis of variance for the traits studied under natural infestation in the four environments in 2018

\begin{tabular}{|c|c|c|c|c|c|c|c|}
\hline Source & $\mathrm{df}$ & SVR 1 & SVR 2 & SVR 3 & SVR 4 & INC 1 & INC 2 \\
\hline Env & 3 & $701.53^{\star *}$ & $362.98^{\star *}$ & $4.54^{\star *}$ & -- & $22.54^{\star *}$ & $8.37^{\star *}$ \\
\hline Variety $(\mathrm{V})$ & 19 & 2.40 & 2.2 & $9.98^{\star *} \quad 2$ & $20.42^{\star *}$ & 0.08 & $0.19^{\star}$ \\
\hline Rep (Env) & 8 & 2.44 & 2.03 & $2.15^{\star \star}$ & $2.75^{\star \star}$ & $0.64^{* *}$ & $0 . .31^{\star *}$ \\
\hline Env $\mathrm{x} V$ & 57 & 2.2 & 1.92 & $2.16^{\star *}$ & 0.001 & 0.10 & $0.16^{\star *}$ \\
\hline Error & 152 & 2.71 & 2.06 & 0.69 & 0.92 & 0.10 & 0.09 \\
\hline Source & INC 3 & INC 4 & PH 1 & $\mathrm{PH} 2$ & \multicolumn{2}{|c|}{ PH 3} & $\mathrm{PH} 4$ \\
\hline Env & $5.78^{\star *}$ & $20.67^{\star *}$ & $1416.84^{* *}$ & $8009.34^{* *}$ & \multicolumn{2}{|c|}{$12091.77^{\star *}$} & $24084.52^{\star *}$ \\
\hline Variety (V) & $0.74^{* *}$ & $0.75^{\star \star}$ & $83.92^{\star *}$ & 16.29 & \multicolumn{2}{|c|}{$624.76^{* *}$} & $120.10^{\star}$ \\
\hline Rep (Env) & 0.14 & $0.24^{\star *}$ & 3.12 & $375.66^{\star *}$ & \multicolumn{2}{|c|}{$54.89^{* *}$} & $1032.16^{* *}$ \\
\hline Env $x \mathrm{~V}$ & 0.13 & $0.25^{\star \star}$ & $6.10^{*}$ & 27.65 & \multicolumn{2}{|c|}{$60.41^{\star *}$} & 83.09 \\
\hline Error & 0.11 & 0.09 & 3.26 & 20.57 & \multicolumn{2}{|c|}{23.97} & 76.48 \\
\hline
\end{tabular}

SVR 1, 2, 3 \& 4: FAW severity (scale1-9) at 1, 2, 3 \& 4 weeks after infestation; INC 1, 2, 3 \& 4: FAW incidence (\%) at 1, 2, 3 \& 4 weeks after infestation; PH 1, 2, $3 \& 4$ : Plant height at 1, 2, $3 \& 4$ weeks after infestation; df: degree of freedom; ${ }^{*}, *$ : Significant at $p$ $=0.05$ and 0.01 respectively

Table 5: The top maize varieties selected under artificial and natural

\begin{tabular}{ccc}
\hline s/n & Artificial infestation & Natural infestation $^{*}$ \\
\hline 1 & BR LNTP-Y C6 & BR 9943 DMRSR \\
2 & ART/98/SW6-OB-W & TZBR ELD 4-W C2 \\
3 & SUWAN-1-SR-Y & TZBR COMP 1-Y C3 \\
4 & AMA TZBR-W C4 & AMA TZBR-W C4 \\
5 & TZBR ELD 4-Y C2 & SUWAN 1-SR Y \\
\hline
\end{tabular}

FAW infestation using RSI ( $25 \%$ selection intensity)

* Selection under natural infestation is based on the pooled data for the four environments 
environments (Giaveno et al., 2004) or variation of the buildup of the pest in different environments used for this study. The significant mean squares of variety showed high level of variability among the varieties for resistance to FAW. Oliveira et al. (2018) working on popcorn under fall armyworm reported significant differences among genotypes for both nutritional and physical traits.

The result of RSI corroborates the outcome of cluster analysis under both conditions. Three of the top 5 selected varieties under artificial infestation using RSI are stem borer resistant and also belong to the best groups under cluster analysis. Under natural environment, four of the selected varieties are stem borer resistant. Some of the varieties selected by RSI clustered in the same group with the resistant check 'BR LNTP-Y $\mathrm{C}_{6}$, while some stood alone in distinct groups. This study suggested some levels of relationship between stem borer resistance and
FAW resistance. Hence, multiple insect resistance could be developed in these varieties. Ni et al. (2011) recorded similar observation in the western corn rootworm resistant variety, CRW3(S1) C6 which showed resistance to the FAW. Previous reports on multiple insect resistance has been limited to similar plant tissues, such as multiple leaf-feeding insects (Wilson et al., 1995; Abel et al., 2000), and multiple ear-feeding insects and ear-colonizing diseases (Ni et al., 2007; Ni et al., 2008).

It is worthy to note that 'ART/98/SW6-OB' and 'SUWAN 1-SR' selected by RSI, and also grouped with the resistant check in cluster analysis are non-stem borer resistance varieties. 'ART/98/SW6-OB' is a quality protein maize developed by the Institute of Agricultural research and Training (IAR\&T), while 'SUWAN 1 SR' is a streak resistant maize variety.

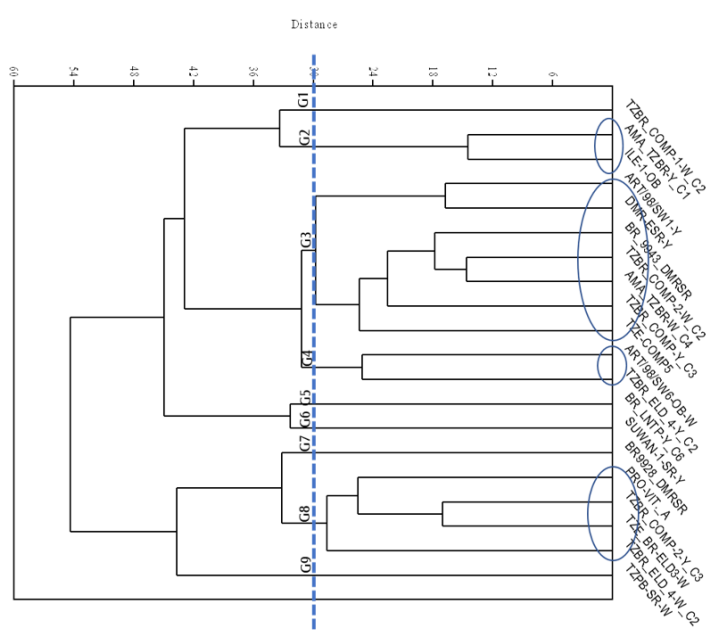

Figure 1: Dendrogram of the 20 maize varieties under artificial fall armyworm infestation based on Euclidean similarity distance

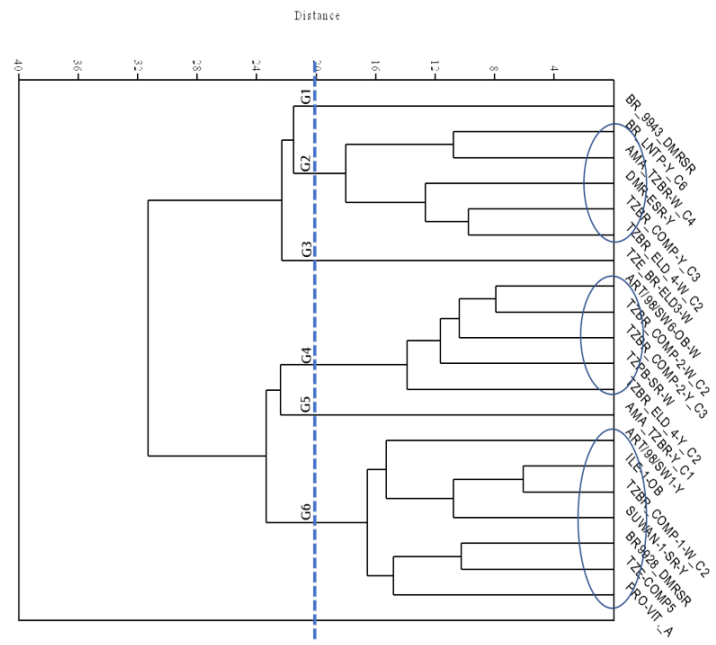

Figure 2: Dendrogram of the 20 maize varieties under natural FAW infestation based on Euclidean similarity distance 


\section{CONCLUSION}

This study suggested that there is a relationship between resistance to stem borer and FAW. It also revealed that varieties BR LNTP-Y C 6 , AMA TZBR-W $\mathrm{C}_{4}$ and TZBR ELD $4 \mathrm{C}_{2}$ ART/98/SW6-OB and SUWAN 1-SR are good resistant source which could be used in a breeding program for resistance to FAW.

\section{REFERENCES}

Abel, C.A., Berhow, M.A., Wilson, R.L., Binder, B.F. \& Hibbard, B.E. (2000). Evaluation of conventional resistance to European corn borer (Lepidoptera: Crambidae) and western corn rootworm (Coleoptera: Chrysomelidae) in experimental maize lines developed from a backcross breeding program. Journal of Economic Entomology, 93, 1814-1821. https://doi.org/10.1603/0022-0493-93.6.1814

Abrahams, P., Bateman, M., Beale, T., Clottey, V., Cock, M., Colmenarez, Y. . ... (2017). Fall armyworm: Impacts and Implications for Africa. Department of Biosciences, University of Exeter. CABI, UK.

Giaveno, C.D \& Ferrero, J. (2003). Introduction of tropical maize genotypes to increase silage production in the central area of Santa Fe, Argentina. Crop Breeding and Applied Biotechnology, 3, 203-208. https://doi.org/10.12702/19847033.v03n02a01

Giaveno, C.D., Paravano, A.S., Curis, M.C. \& Portmann, E. (2004). Breeding maize for resistance to fall armyworm (Spodoptera frugiperda) in Argentina: genetic and environmental effects. Crop Breeding and Applied Biotechnology, 4, 434-440. https://doi.org/10.12702/1984-7033.v04n04a09

Huesing, J. (2017). Fall Armyworm in Africa: A Guide for Integrated Pest Management. SDSN carbon-free e-conference 'Responding to Fall Armyworm in Africa', 22-26 October 2017. USAID Washington DC, USA.

Laznik, Z., Toth, T., Lakatos, M.,Vidrih, S. \&Trdan, S. (2010). Control of the Colorado potato beetle (Leptinotarsa decemlineata [Say]) on potato under field conditions: a comparison of the efficacy of foliar application of two strains of Steinernema feltiae (Filipjev) and spraying with thiametoxam. Journal of Plant Diseases and Protection, 117, 129-135. https://doi.org/10.1007/BF03356348
Mulumba, N.N \& Mock, J.J. (1978). Improvement of yield potential of Eto Blanco maize (Zea mays L.) population by breeding for plant traits. Egyptian Journal of Genetics and Cytology, 7, 40-51.

Ni, X. Z., Chen, Y. G., Hibbard, B. E., Wilson, J. P., Williams, W. P., Buntin, G. D., Ruberson, J. R. \& Li, X. C. (2011). Foliar resistance to fall armyworm in corn germplasm lines that confer resistance to root- and ear-feeding insects. Florida Entomologist, 94(4), 971-981. https://doi. org/10.1653/024.094.0434

Ni, X., Krakowsky, M.D., Buntin, G.D., Rector, B.G., Guo, B. \& Snook, M.E. (2008). Identification of multiple ear-colonizing insect and disease resistance in CIMMYT maize inbred lines with varying levels of silk maysin. Journal of Economic Entomology, 101, 1455-1465. https://doi.org/10.1093/ jee/101.4.1455

Ni, X., Xu, W., Krakowsky, M.D., Buntin, G. D., Brown, S. L., Lee, R.D. \& Coy, A.E. (2007). Field screening of experimental corn hybrids and inbred lines for multiple ear-feeding insect resistance. Journal of Economic Entomology, 100, 1704-1713. https://doi.org/10.1093/jee/100.5.1704

Oliveira N.C., Suzukawa, A.K., Pereira, C.B., Santos, H.V., Hanel, A., De Albuquerque, F.A. \& Scapim, C.A. (2018). Popcorn genotypes resistance to fall armyworm. Ciência $\mathrm{Ru}$ ral, Santa Maria, 48(2), 1-6. https://doi.org/10.1590/0103$8478 \mathrm{cr} 20170378$

Oloyede-Kamiyo, Q.O., Ajala, S.O. \& Akoroda, M.O. (2011). Variability for resistance to the pink stem borer (Sesamia calamistis Hampson) and the sugarcane borer (Eldana saccharina Walker) in two tropical maize populations. Maydica ,56, 257-264.

Prasanna, B.M. (2018). Breeding for Native Genetic Resistance to Fall Armyworm. CIMMYT. Hohenheim; Sept 11, 2018.

Williams, W. P., Davis, F. M., Buckley, P. M., Hedin, P. A., Baker, G. T. \& Luthe, D. S. (1998). Factors associated with resistance to fall armyworm (Lepidoptera: Noctuidae) and southwestern corn borer (Lepidoptera: Crambidae) in corn at different vegetative stages. Journal of Economic Entomology, 91(6), 1471-1480. https://doi.org/10.1093/jee/91.6.1471

Wilson, R. L., Abel, C. A., Wiseman, B. R., Davis, F. M., Williams, W. P., Barry, B. D. \& White, W. H. (1995). Evaluation for multiple pest resistance in European corn borer, Ostrinia nubilalis resistant maize accessions from Peru. Journal of Kansas Entomological Society, 68, 326-331. 